Brazilian Journal

of Chemical

ISSN 0104-6632

Engineering

\title{
TREATMENT OF WASTEWATER WITH HIGH FAT CONTENT EMPLOYING AN ENZYME POOL AND BIOSURFACTANT: TECHNICAL AND ECONOMIC FEASIBILITY
}

\author{
Fernanda R. C. Damasceno ${ }^{1}$, Elisa D. Cavalcanti-Oliveira ${ }^{2}$, Ioannis K. \\ Kookos $^{3}$, Apostolis A. Koutinas ${ }^{4}$, Magali C. Cammarota ${ }^{5 *}$ and Denise \\ M. G. Freire ${ }^{2}$ \\ ${ }^{1}$ Federal University of Rio de Janeiro, Campus Xerém, Duque de Caxias, Brazil, \\ fernandadocarmo@xerem.ufrj.com \\ ${ }^{2}$ Department of Biochemistry, Institute of Chemistry, Federal University of Rio de Janeiro, Rio de Janeiro, \\ Brazil, elisadcc@gmail.com, freire@iq.ufrj.br \\ ${ }^{3}$ Department of Chemical Engineering, University of Patras, Rio 26504, Patras, \\ Greece, i.kookos@chemeng.upatras.gr \\ ${ }^{4}$ Department of Food Science and Human Nutrition, Agricultural University of Athens, Athens, Greece, \\ akoutinas@aua.gr \\ ${ }^{5}$ Department of Biochemical Engineering, School of Chemistry, Federal University of Rio de Janeiro, \\ Rio de Janeiro, Brazil, christe@eq.ufrj.br
}

(Submitted: December 23, 2016; Revised: February 20, 2017; Accepted: February 23, 2017)

\begin{abstract}
The combination of $0.5 \%$ weight per volume (w/v) crude enzyme consortia produced by solid state fermentation with Penicillium brevicompactum and 27 milligrams per liter $(\mathrm{mg} / \mathrm{L})$ of rhamnolipid biosurfactant produced by submerged fermentation with Pseudomonas aeruginosa was employed to pretreat wastewater from a poultry slaughterhouse in bench upflow anaerobic sludge blanket (UASB) bioreactors. One bioreactor was fed with untreated wastewater (Control) and another with pretreated wastewater (Test). Under an organic loading rate of $11 \mathrm{~kg} \mathrm{COD} / \mathrm{m}^{3} . \mathrm{d}$, the Test bioreactor showed higher specific methane production $\left(67.8 \mathrm{~mL} \mathrm{CH}_{4}(\mathrm{STP}) / \mathrm{g} \mathrm{COD}\right.$ removed), higher chemical oxygen demand (COD) (91.2\%), and oil and grease (O\&G) (95.8\%) removal than the Control bioreactor, which produced $36.1-16.9 \mathrm{~mL} \mathrm{CH}_{4}$ (STP)/g COD removed with $72.5 \%$ COD removal and $48 \%$ O\&G removal. The Control bioreactor experienced five clogging episodes due to the accumulation of fat on the surface, while the Test bioreactor operated without operational problems. The scum of the Control bioreactor contained more than 10 times higher quantities of fat than the Test bioreactor. The economic analysis indicated that such alternative technology has lower costs than conventional technology.
\end{abstract}

Keywords: Enzymes, anaerobic processes, bioreactors, wastewater treatment, fat, rhamnolipid.

*Corresponding author: Department of Biochemical Engineering, School of Chemistry, Federal University of Rio de Janeiro, Cidade Universitária, Av. Athos da Silveira Ramos, 149, Bl. E, Sl. 203, Ilha do Fundão, 21941-909, Rio de Janeiro, Brazil, Phone: +55 21 3938- 7568; Fax: +55 21 3938- 7567; E-mail address: christe@eq.ufrj.br 


\section{INTRODUCTION}

Due to the high energy potential of lipids present in wastewater from poultry slaughtering plants, the anaerobic biological treatment is highly attractive for generating large amounts of methane, which can be used as an energy source by the poultry industry (Angelidaki and Sanders, 2004; Alves et al., 2009).

Although efficient, anaerobic biological processes may present problems during the treatment of wastewater with high levels of fat, such as the development of sludge with low activity, with inadequate physical characteristics and high tendency for flotation, production of scum, clogging of sludge bed, and drag of biomass, which leads to lost efficiency and even the collapse of the reactor. Moreover, fat adsorption occurs at the surface of the sludge, hindering the assimilation of nutrients and decreasing the rate of substrate conversion (Pereira et al., 2004; Jeganathan et al., 2007; Alves et al., 2009).

Fat accumulation in biomass and the operational problems mentioned above occur because the substrate feeding rate becomes faster than the substrate degradation rate. For this reason, the anaerobic biological treatment of wastewater from poultry processing industries is almost always preceded by one or more pretreatment steps to reduce fat concentration (Del Nery et al., 2007; Nardi et al., 2008). Induced and dissolved air flotation, chemically aided or not, is often used to remove oil and grease from wastewater before biological processes. However, the cost of the air and reagents (chemically assisted flotation) is high, the dissolved and / or emulsified material removal efficiency is low, and sometimes sludges that are extremely difficult to treat are produced (Al-Mutairi et al., 2008).

Few studies are available in the literature on the use of enzymes to pretreat effluents from slaughterhouses. When enzymatic pretreatment is employed, the triglycerides are hydrolyzed to fatty acids and glycerol, which improve the efficiency of biodegradation by microorganisms during biological treatment. In a series of studies, Masse et al. $(2001 ; 2003)$ described the use of a commercial pancreatic lipase (PL-250 Genecor International) for the hydrolysis of fat particles from slaughterhouse wastewater. The efficiency of the hydrolysis was confirmed by reducing the particle diameter as well as verifying the production of long chain fatty acids. However, no significant differences were found between reactors fed with pre-hydrolyzed wastewater and reactors fed with unhydrolyzed wastewater in the treatment of a slaughterhouse wastewater containing $550 \mathrm{mg} / \mathrm{L}$ of fat. Dors et al. (2013) studied the addition of commercial pancreatic lipases on biodegradability of wastewater from a poultry processing industry. Enzymatic treatments were performed by varying the enzyme concentrations from 1 to $3 \mathrm{~g} / \mathrm{L}$. When the wastewater was biodegraded for approximately $30 \mathrm{~d}$ at $35^{\circ} \mathrm{C} / 100 \mathrm{rpm}$, the COD removal achieved was 3 times higher than the removal obtained with the raw wastewater. The enzyme concentration did not interfere significantly in the rate of removal of organic material.

Valladão et al. (2009) reported that enzymatic pretreatment $(0.1 \%$ solid enzymatic preparation - SEP, for $4 \mathrm{~h}$ ) of slaughterhouse wastewater in a UASB bioreactor resulted in improved production of methane and higher COD removal (882 $\left.\mathrm{mL} \mathrm{CH}_{4}, 93.5 \%\right)$ than the values obtained when the bioreactor was fed with raw wastewater $\left(642 \mathrm{~mL} \mathrm{CH}_{4}, 91.0 \%\right)$.

The application of biosurfactants in industrial wastewater treatment has been reported in the literature (Nakhla et al., 2003; Daverey and Pakshirajan, 2011). The biosurfactant facilitates the biodegradation by dissolving fats and oils, which can be incorporated directly in the biological process, thus eliminating additional pretreatment processes to remove fat and resulting in lower capital and operating costs (Nakhla et al., 2003).

However, the combined use of enzyme and biosurfactant is a novel approach that could improve the wastewater treatment from food industries with high fat content. It is envisaged that this approach will reduce operational problems, treatment costs, and disposal of waste, while at the same time it could increase the production of methane from anaerobic processes. The objective of this study was to evaluate the technical and economic feasibility of the combined application of rhamnolipid type biosurfactant produced by Pseudomonas aeruginosa PA1 and crude enzyme consortia produced by the fungus Penicillium brevicompactum in anaerobic treatment of wastewater from poultry processing industry with high-fat content.

\section{MATERIALS AND METHODS}

\section{Crude enzyme consortia production}

The crude enzyme consortia was produced using solid-state fermentation of the fungus Penicillium brevicompactuum, which was isolated from an industrial Orbignya oleifera (babassu) oil extraction waste (Freire et al., 1997). The agro-industrial waste generated in the babassu seed oil extraction, known 
as babassu cake, was used as the culture medium. Fermentations were conducted in $600 \mathrm{ml}$ beakers containing $15 \mathrm{~g}$ of babassu cake with $65 \%$ initial moisture using procedures described in Gutarra et al. (2005). The beakers were autoclaved at $121^{\circ} \mathrm{C} / 15$ min and, after cooling, they were inoculated with $10^{7}$ spores/g of dry cake and incubated for $48 \mathrm{~h}$ in a fermentation chamber at $30^{\circ} \mathrm{C}$ and $95 \%$ humidity. At the end of the fermentation process, part of the fermented cake was sampled to determine lipase (average value of $48.6 \pm 5.2 \mathrm{U} / \mathrm{g}$ ) and protease (average value of $3.4 \pm 0.5 \mathrm{U} / \mathrm{g}$ ) activities. One lipase unit was defined as the amount of enzyme that catalyzes the release of one $\mu$ mole of fatty acids per minute, under assay conditions. One protease activity unit was defined as the unit difference in absorbance between the reaction blank and the sample per minute under the assay conditions. The remainder of the fermented cake was vacuum-packed and stored in a freezer $\left(-20^{\circ} \mathrm{C}\right)$ until use.

\section{Biosurfactant production}

Biosurfactant was produced using Pseudomonas aeruginosa PA1 isolated from oil production water at Sergipe, Brazil (Santa Anna et al., 2002), which was grown in optimized medium described by Santos et al. (2002). After seven days, fermentation was stopped and the cell-free crude fermented broth (after centrifugation and sterilization at $121^{\circ} \mathrm{C} / 15 \mathrm{~min}$ ) was characterized for rhamnolipid concentration $(10.2 \mathrm{~g} / \mathrm{L})$, surface tension $(29 \mathrm{mN} / \mathrm{m})$, critical micelle concentration $(\mathrm{CMC}=$ $53.3 \mathrm{mg} / \mathrm{L})$, emulsification index using $\mathrm{n}$-hexadecane $(63 \%)$, and chemical oxygen demand $(\mathrm{COD}=26,609$ $\mathrm{mg} / \mathrm{L})$. The cell-free fermented medium was stored at $-20^{\circ} \mathrm{C}$ until use. Sterilization of the cell-free medium denatured all proteins with catalytic activity that could influence the hydrolysis of oil and grease and/or proteins from the wastewater. The only molecule with interfacial activity in this medium was rhamnolipid (Santa Anna et al., 2002).

\section{Wastewater and sludge characterization}

The wastewater used was collected in a local poultry slaughterhouse, between the equalization and flotation steps, analyzed using standard methodologies (Greenberg et al., 2005), and kept at $-20^{\circ} \mathrm{C}$ until use. The granular anaerobic sludge was collected in the UASB reactor operated at the same slaughterhouse and presented a concentration of volatile suspended solids (VSS) of $14.7 \mathrm{~g} / \mathrm{L}$ and specific methanogenic activity (SMA) of $0.173 \mathrm{~g} \mathrm{COD}_{\mathrm{CH} 4} / \mathrm{gVSS}$.d.

\section{Pretreatment of the wastewater with crude enzyme consortia and biosurfactant}

The conditions of this pretreatment were determined in experiments in which different combinations of enzyme consortia, biosurfactant, time, and temperature were evaluated on solubilization/ hydrolysis of fats and subsequent anaerobic treatment conducted in sequencing batches (Damasceno et al., 2012). Wastewater from a poultry slaughterhouse, containing around $1300 \mathrm{mg} \mathrm{O} \& \mathrm{G} / \mathrm{L}$, was pretreated with $0.5 \%(\mathrm{w} / \mathrm{v})$ of the solid enzymatic preparation (SEP) and $27 \mathrm{mg} / \mathrm{L}$ of biosurfactant for $4 \mathrm{~h}$ at $30^{\circ} \mathrm{C}$ and $150 \mathrm{rpm}$. This condition produced the best synergistic effect for the availability/hydrolysis of fat through the combined action of biosurfactant and enzyme consortia, with promising results for COD removal, methane production, and low fat accumulation. After hydrolysis, the babassu cake was separated from the wastewater by screening (mesh 14), and the filtrate (hydrolyzed wastewater) was maintained at $4^{\circ} \mathrm{C}$ until used in the bioreactor feed.

\section{Experimental Equipment}

The anaerobic treatment was carried out in two UASB reactors that were built using acrylic fiber (1.08 L working volume). The dimensions of the bioreactors were $8.5 \mathrm{~cm}$ in diameter and $26.1 \mathrm{~cm}$ in height. Porcelain beads with a mean diameter of 0.7 $\mathrm{cm}$ were distributed on the base of the bioreactors to allow better distribution of feed and to prevent formation of preferential channels. Three sampling points were located at $4 \mathrm{~cm}, 8 \mathrm{~cm}$, and $13.5 \mathrm{~cm}$ from the base of the bioreactors. The biogas was vented in the upper portion of the UASB reactors immediately after passing through a three-phase separation system, consisting of one inverted funnel with a diameter of $6.8 \mathrm{~cm}$. A deflector ring, with $45^{\circ}$ angle, was installed at a height of $19.35 \mathrm{~cm}$, at $0.5 \mathrm{~cm}$ away from the threephase separator. The gas outlet was connected to a Ritter biogas meter (Milligascounter). After inoculation with $360 \mathrm{~mL}$ of anaerobic sludge, the continuous feed (prepared two times per day to prevent deterioration and under agitation to prevent solid material settling) started with hydraulic retention times (HRT) of 20 h. One UASB bioreactor was fed with pretreated wastewater (called the Test Reactor), while the other was fed with raw wastewater (untreated, called the Control Reactor). The bioreactors operated at $30^{\circ} \mathrm{C}$ for 187 days. The anaerobic sludge was adapted to the poultry processing wastewater in the initial 44 days, during which there was a progressive increase 
in the COD removal efficiency. During operation, two regimes were evaluated according to the organic load: $1^{\text {st }}$ (with HRT of $20 \mathrm{~h}$ and $6 \mathrm{~kg} \mathrm{COD} / \mathrm{m}^{3} . \mathrm{d}$ for 68 days) and $2^{\text {nd }}$ (with HRT of $12 \mathrm{~h}$ and $11 \mathrm{~kg} \mathrm{COD} / \mathrm{m}^{3} . \mathrm{d}$ for 75 days). At the end of each regime, the three phase separators were cleaned and samples were collected from the scum to establish the O\&G percentage. Sludge samples were also collected at different heights of the bioreactors to determine the VSS concentration and the percentage of O\&G adhered to the biomass.

The performance of both bioreactors was monitored by analysis of $\mathrm{pH}$, flux, total suspended solids, fixed and volatile, COD, volatile acidity, alkalinity, O\&G, methane and biogas production. The parameters used to monitor the UASB bioreactors were analyzed through the Student $t$ test with significance level of 5\% using the Statistica software 5.0.

\section{Analytical Methods}

The lipase activity of the fermented cake (SEP) was determined for each solid-state fermentation, which was conducted according to Gombert et al. (1999). After fermentation, phosphate buffer $(100 \mathrm{mM}, \mathrm{pH}$ $7,5 \mathrm{~mL} / \mathrm{g}$ ) was added to each beaker containing the fermented solids. The enzyme extraction was carried out in a rotary shaker at $35^{\circ} \mathrm{C}$ and $200 \mathrm{rpm}$ for 20 min. Later solid-liquid separation was performed by pressing, followed by centrifugation at $2000 \mathrm{~g}$ for $5 \mathrm{~min}$ (Gombert et al., 1999). The supernatant was used to determine lipase and protease activities as previously described (Freire et al., 1997). In the cell-free crude fermented broth containing the biosurfactant, the rhamnolipid concentration was determined as rhamnose using the method described by Pham et al. (2004). The emulsification index was determined according to the method described by Cooper and Goldenberg (1987), and the surface tension was analyzed in a tensiometer Aqua-Pi (Kibron Inc., Helsinki, Fimland) at $25^{\circ} \mathrm{C}$, based on the Du Noüy (1925) method using small probes. The critical micelle concentration (CMC) was determined using the method described by Cooper et al. (1979).

Biogas composition was determined in a Varian Micro GC 4900 gas chromatograph using a $10 \mathrm{~m} \mathrm{x}$ $0.32 \mathrm{~mm}$ PPQ column, column temperature of $50^{\circ} \mathrm{C}$, thermal conductivity detector $(\mathrm{TCD})$ at $250^{\circ} \mathrm{C}$, injector temperature of $80^{\circ} \mathrm{C}$, and helium as carrier gas. The other parameters used in the wastewater and sludge characterization and to monitor anaerobic bioreactors $(\mathrm{pH}, \mathrm{COD}, \mathrm{O} \& \mathrm{G}$, volatile acidity, total alkalinity, suspended solids, fixed and volatile, total nitrogen, and total phosphorus) were determined according to the Standard methods (Greenberg et al., 2005).

\section{Techno-economic evaluation}

A comparative preliminary techno-economic analysis was carried out to evaluate if the new process that employs the biosurfactant and the crude enzyme consortia for poultry wastewater treatment (conditions described in topics Pretreatment of the wastewater with crude enzyme consortia and biosurfactant, and Experimental Equipment) is cost-competitive in relation to the conventional process that employs floater and chemicals.

The SuperPro Designer software (version 8.0, full license, Intelligen, Inc.) was used to construct process flowsheets as well as perform mass and energy balances of the two processes of wastewater pretreatment. The plant operation of both processes was $24 \mathrm{~h}$ per day ( 3 shifts) and 312 days ( 6 working days x 52 weeks) per year. The flow rate of wastewater was $750 \mathrm{~m}^{3} /$ day. The two processing scenarios were compared based on the total capital investment and the operating cost required for each flowsheet.

The estimate of the fixed capital investment was based on the cost of the installed equipment multiplied by a factor of 1.2 for existing plants (Turton et al., 2012). The working capital was estimated by taking into consideration three months of raw materials and one month of labor (Turton et al., 2012). The total capital investment was calculated as the sum of fixed capital investment and working capital.

The costs to purchase equipment were obtained via vendor quotes except for the equalization tanks that were calculated based on literature data. Sizing of equalization tanks was based on average volume per hour according to recommendations of specialized companies and/or were calculated based on the Brazilian Technical Standards (NBR 7229 - Project, construction and operation of septic tank systems procedure; NBR 6118 - Design of structural concrete - procedure) (ABNT, 1993; 2004) and procedures described in Peters et al. (2003). All the costs to purchase equipment were updated to April, 2015, using the market prices general index (IGP-M), available through the Brazilian Central Bank. The estimation of costs for installed equipment was carried out according to Equation 1 (Turton et al., 2012):

$$
C_{B M}=C_{p} \cdot F_{B M}
$$

where $\mathrm{C}_{\mathrm{BM}}=$ installed equipment $\operatorname{cost} ; \mathrm{C}_{\mathrm{p}}=\cos \mathrm{t}$ to purchase equipment; and $\mathrm{F}_{\mathrm{BM}}=$ Bare module factor. 
The operating cost was calculated using Equation 2 including the cost of raw materials $\left(\mathrm{C}_{\mathrm{RM}}\right)$, utilities $\left(\mathrm{C}_{\mathrm{UT}}\right)$, labor (operating labor and direct supervision) $\left(\mathrm{C}_{\mathrm{OL}}\right)$, waste treatment $\left(\mathrm{C}_{\mathrm{WT}}\right)$, supplies, laboratory charges, and costs related to fixed capital (equipment maintenance and depreciation) $\left(\mathrm{F}_{\mathrm{CI}}\right)$ (Turton et al., 2012):

$$
C_{O M}=0.243 F_{C I}+2.215 C_{O L}+C_{R M}+C_{U T}+C_{W T}
$$

The plant life cycle was set as 10 years (Turton et al., 2012). Costs for raw materials were obtained via quotes from chemical industries and specialized websites. The adopted costs were: coagulant ferric chloride with density $1.42 \mathrm{~kg} / \mathrm{L}$ (US\$ 0.58/kg, YIXING BLUWAT CHEMICALS), anionic flocculant polyacrylamide for wastewater (US\$2.25/kg, CHANGZHOU KEWEI TIANSHI ENVIRONMENTAL TECHNOLOGY), rhamnolipid biosurfactant (US\$ 16.12/L, VICTEX CHEMICAL INDUSTRIES), and lipase enzyme 20,000 U/g (US\$ 2.36/kg, AODIER GROUP). To calculate the cost of labor, a monthly salary and additional charges of US\$ 272.48 per operator were considered, which is based on Brazilian law. The plant operates with 3 shifts per day and 6 days per week. The conventional plant requires 5 working stations per shift, whereas the novel plant requires 3 working stations per shift. The labor requirements were calculated according to the methodology proposed by Ulrich and Vasudevan (2004) using a fraction of operator per equipment, while the sum of operators for all equipment was multiplied by 3.9.The cost of the waste disposal (US\$ 66.00/ton) was calculated according to the weight allocated to the landfill, considering humidity $40 \%$ to $70 \%$, and data provided by the company responsible for the disposal of solid waste from a poultry processing industry. The quantities of utilities required were estimated by the software SuperPro Designer, according to the specifications of the equipment and the volume of treated wastewater. The utilities required for the conventional plant were electricity (US\$ $0.12 / \mathrm{kWh}$ - motor pumps, agitators, and floater) and steam 15 $\mathrm{kgf} / \mathrm{cm}^{2}$ (US\$ 44.38/ton - for heating the tri-decanter, equipment used to remove excess moisture from the fat that was separated in flotation). The alternative plant required only electricity (motor pumps for filling and emptying of equalization tanks and agitators). The costs of utilities are values experienced in Brazilian industries and were updated to April, 2015, using the market prices general index (IGP-M), available through the Brazilian Central Bank.

\section{RESULTS AND DISCUSSION}

\section{Performance of UASB reactors fed with pretreated wastewater (Test) and raw wastewater (Control)}

Table 1 summarizes the results obtained during the operation of the Control and Test bioreactors in both feeding regimes: in the $1^{\text {st }}$ regime, the organic loading rate (OLR) was maintained at around $6 \mathrm{~kg} \mathrm{COD} /$ $\mathrm{m}^{3} . \mathrm{d}$, while in the $2^{\text {nd }}$ regime, it was increased to $11 \mathrm{~kg}$ $\mathrm{COD} / \mathrm{m}^{3}$.d. The OLR values of the Control and Test bioreactors were similar, which is important to rule out any influence of the applied organic load on the operating efficiency of the bioreactors. The variation over time in both bioreactors was due to the use of industrial wastewater, which introduced variability and made it difficult to control every collection.

In both raw and pretreated wastewater, the $\mathrm{pH}$ of the feed was adjusted to 7.0. During operation, there was an increasing trend in $\mathrm{pH}$ values for the outputs of both bioreactors. However, the values remained within the range described as ideal for the operation of UASB reactors (Table 1). During the $1^{\text {st }}$ regime, there was a similar behavior for total alkalinity in both bioreactors, which remained relatively constant. In the $2^{\text {nd }}$ regime, although the observed averages remained statistically the same (Table 1), total alkalinity in the two bioreactors showed a downward trend, which was probably related to a greater accumulation of acids in the reactors. The volatile fatty acids (VFA) present in the bioreactor effluent, such as acetic, propionic, and butyric acids, which were derived from decomposition of organic compounds during digestion, were almost constant in the first regime in the two bioreactors. In the second regime, there was a slight variation in the VFA concentrations in both bioreactors. However, despite this variation, the average VFA concentrations remained statistically equal. In the first and second regimes, the relationship between VFA/Alkalinity remained low for both Control and Test bioreactors, and within the limits recommended in the literature for anaerobic digestion (between 0.1 and $0.5 \mathrm{mg}$ acetic $\mathrm{acid} / \mathrm{mg} \mathrm{CaCO}_{3}$ ). The values obtained were similar in statistical analysis between bioreactors and regimes (Table 1).

Note that there were variations in the total influent COD for the two bioreactors, reflecting the variability of the wastewater, as previously mentioned. It is noteworthy that the values of the influent COD were close in both bioreactors $(5304 \pm 103 \mathrm{mg} / \mathrm{L}$ - average of the two regimes for the Control bioreactor and 
Table 1. Summary of the results obtained during the operation of the Control and Test bioreactors.

\begin{tabular}{|c|c|c|c|c|}
\hline \multirow[t]{2}{*}{ Parameter } & \multicolumn{2}{|c|}{ Control } & \multicolumn{2}{|c|}{ Test } \\
\hline & $1^{\text {stregime }}$ & $2^{\text {nd }}$ regime & $1^{\text {stregime }}$ & $2^{\text {nd }}$ regime \\
\hline OLR $\left(\mathrm{kg} \mathrm{COD} / \mathrm{m}^{3} . \mathrm{d}\right)$ & $6.3 \pm 0.6^{\mathrm{AC}}$ & $10.8 \pm 1.2^{\mathrm{BC}}$ & $6.0 \pm 1.0^{\mathrm{AC}}$ & $11.1 \pm 1.3^{\mathrm{BC}}$ \\
\hline $\mathrm{pH}_{\text {influent }}$ & $6.6 \pm 0.2^{\mathrm{AC}}$ & $6.7 \pm 0.4^{\mathrm{AC}}$ & $6.5 \pm 0.3^{\mathrm{AC}}$ & $6.7 \pm 0.4^{\mathrm{BC}}$ \\
\hline $\mathrm{pH}_{\text {effluent }}$ & $7.6 \pm 0.4^{\mathrm{AC}}$ & $7.4 \pm 0.4^{\mathrm{BC}}$ & $7.6 \pm 0.3^{\mathrm{AC}}$ & $7.4 \pm 0.3^{\mathrm{BC}}$ \\
\hline VFA (mg HAc/L) & $196 \pm 42^{\mathrm{AC}}$ & $268 \pm 96^{\mathrm{AC}}$ & $181 \pm 25^{\mathrm{AC}}$ & $222 \pm 79^{\mathrm{AC}}$ \\
\hline Alkalinity $\left(\mathrm{mg} \mathrm{CaCO}_{3} / \mathrm{L}\right)$ & $914 \pm 68^{\mathrm{AC}}$ & $983 \pm 243^{A C}$ & $998 \pm 160^{\mathrm{AC}}$ & $976 \pm 247^{\mathrm{AC}}$ \\
\hline VFA/Alkalinity & $0.21 \pm 0.03^{\mathrm{AC}}$ & $0.28 \pm 0.08^{\mathrm{AC}}$ & $0.18 \pm 0.02^{\mathrm{AC}}$ & $0.23 \pm 0.10^{\mathrm{AC}}$ \\
\hline Total $\mathrm{COD}_{\text {influent }}(\mathrm{mg} / \mathrm{L})$ & $5231 \pm 520^{\mathrm{AC}}$ & $5377 \pm 612^{\mathrm{AC}}$ & $5000 \pm 829^{A C}$ & $5537 \pm 668^{\mathrm{AC}}$ \\
\hline Total $\mathrm{COD}_{\text {effluent }}(\mathrm{mg} / \mathrm{L})$ & $546 \pm 206^{\mathrm{AC}}$ & $1470 \pm 806^{\mathrm{BC}}$ & $480 \pm 223^{\mathrm{AC}}$ & $489 \pm 238^{\mathrm{AD}}$ \\
\hline Total COD removal (\%) & $89.1 \pm 4.4^{\mathrm{AC}}$ & $72.5 \pm 15.6^{\mathrm{BC}}$ & $90.2 \pm 5.0^{\mathrm{AC}}$ & $91.2 \pm 4.0^{\mathrm{AD}}$ \\
\hline Soluble $\mathrm{COD}_{\text {influent }}(\mathrm{mg} / \mathrm{L})$ & $1415 \pm 147^{\mathrm{AC}}$ & $1487 \pm 194^{\mathrm{AC}}$ & $1612 \pm 200^{\mathrm{AD}}$ & $1580 \pm 209^{\mathrm{AC}}$ \\
\hline Soluble $\mathrm{COD}_{\text {effluent }}(\mathrm{mg} / \mathrm{L})$ & $190 \pm 55^{\mathrm{AC}}$ & $269 \pm 87^{\mathrm{BC}}$ & $166 \pm 61^{\mathrm{AC}}$ & $154 \pm 51^{\mathrm{AD}}$ \\
\hline Soluble COD removal (\%) & $86.1 \pm 4.4^{\mathrm{AC}}$ & $82.0 \pm 6.6^{\mathrm{BC}}$ & $89.5 \pm 4.0^{\mathrm{AD}}$ & $90.4 \pm 4.0^{\mathrm{AD}}$ \\
\hline$O \& G_{\text {influent }}(\mathrm{mg} / \mathrm{L})$ & $1243 \pm 191^{\mathrm{AC}}$ & $1240 \pm 119^{\mathrm{AC}}$ & $1229 \pm 185^{\mathrm{AC}}$ & $1185 \pm 97^{\mathrm{AC}}$ \\
\hline$O \& G_{\text {effluent }}(\mathrm{mg} / \mathrm{L})$ & $164 \pm 37^{\mathrm{AC}}$ & $626 \pm 337^{\mathrm{BD}}$ & $49 \pm 31^{\mathrm{AC}}$ & $50 \pm 32^{\mathrm{AC}}$ \\
\hline O\&G removal (\%) & $87.0 \pm 3.0^{\mathrm{AC}}$ & $48.0 \pm 29.0^{\mathrm{BC}}$ & $96.0 \pm 3.0^{\mathrm{AD}}$ & $95.8 \pm 3.0^{\mathrm{AD}}$ \\
\hline Scum O\&G (mg/L) & $1642 \pm 2095^{\mathrm{AC}}$ & $10548 \pm 2773^{\mathrm{BC}}$ & $155 \pm 8^{\mathrm{AD}}$ & $904 \pm 564^{\mathrm{BD}}$ \\
\hline $\mathrm{CH}_{4}(\%)$ & $78 \pm 4^{\mathrm{AC}}$ & $70 \pm 5^{\text {BC }}$ & $79 \pm 3^{\mathrm{AD}}$ & $80 \pm 2^{\mathrm{BD}}$ \\
\hline $\begin{array}{l}\text { Biogas production (STP } \\
\mathrm{mL} / \mathrm{d})^{*}\end{array}$ & 436.3 & $\begin{array}{c}709.5 \\
(143.9)\end{array}$ & 598.5 & 662.2 \\
\hline $\begin{array}{l}\mathrm{SMP}\left(\mathrm{STP} \mathrm{mL} \mathrm{CH}_{4} / \mathrm{g}\right. \\
\left.\mathrm{COD}_{\text {removed }}\right)\end{array}$ & 59.2 & $\begin{array}{c}36.1 \\
(16.9)\end{array}$ & 71.6 & 67.8 \\
\hline $\operatorname{VSS}_{\text {reactor }}(\mathrm{g} / \mathrm{L})$ & 20.2 & 3.2 & 23.7 & 21.4 \\
\hline
\end{tabular}

*During the operation of the $2^{\text {nd }}$ regime, biogas production in the Control reactor remained at a higher value than that obtained in the $1^{\text {st }}$ regime (until the $95^{\text {th }}$ day). Thereafter, biogas production declined and maintained a much lower biogas production value (in parentheses). Test $t-\alpha=0.05$, identical letters mean statistical similarity. A and $\mathrm{B}=$ comparison between the $1^{\text {st }}$ and $2^{\text {nd }}$ regimes of each bioreactor; $\mathrm{C}$ and $\mathrm{D}=$ comparison between average values obtained in Control and Test bioreactors in the $1^{\text {st }}$ regime or $2^{\text {nd }}$ regimes.

$5269 \pm 380 \mathrm{mg} / \mathrm{L}$ - average of the two regimes for the Test bioreactor), which could rule out the influence of different applied load values on the behavior of the treatment systems. The Control bioreactor presented a total average COD effluent 2.7 times higher in the $2^{\text {nd }}$ operating regime, while the Test bioreactor maintained statistically equal values in the $1^{\text {st }}$ and $2^{\text {nd }}$ regimes (Table 1). In the $2^{\text {nd }}$ regime of the Control bioreactor, increased OLR caused greater variability of the total COD effluent. In this regime, the outlet piping of the effluent clogged five times because of the accumulation of solids on the top of the bioreactor, probably due to adsorption of fat onto sludge particles, followed by flotation of these particles to the surface. Several authors mention the flotation and subsequent washout of the sludge as disadvantages of the treatment of effluents with high fat content in granular sludge reactors (Jeganathan et al., 2006; Alves et al., 2009).

The results of influent soluble COD show values for the Test bioreactor that are $12 \%$ and $6 \%$ higher in the $1^{\text {st }}$ and $2^{\text {nd }}$ regimes, respectively. This can be explained by the application of biosurfactant and enzyme consortia in the wastewater pretreatment. With respect to the soluble COD effluent, the values obtained in both bioreactors were very close, although the Control bioreactor displayed an increase of $29 \%$ in the $2^{\text {nd }}$ regime (Table 1 ).

Variations in the COD removal efficiencies in the anaerobic bioreactors throughout the operational period and under the two feeding conditions are shown in Table 1. The total and soluble average COD removal efficiencies achieved indicate that the Test bioreactor remained stable even with increasing organic load from the $1^{\text {st }}$ to the $2^{\text {nd }}$ regime, with values statistically equal to the total and soluble COD removal in both regimes (Table 1). The Control bioreactor showed a small reduction of soluble COD removal and a $19 \%$ decrease in total COD removal from one regime to the other (Table 1). This decrease in efficiency can be attributed to the particulate matter present in the wastewater without pretreatment, particularly insoluble fat. 
By increasing the OLR and consequently decreasing the hydraulic retention time, the Control bioreactor reduced its O\&G removal efficiency by $45 \%$ ( $87 \%$ in the $1^{\text {st }}$ regime to $48 \%$ in the $2^{\text {nd }}$ regime), which may be attributed to the increased total COD output provided by the Control bioreactor. On the other hand, in the Test bioreactor, the effluent O\&G concentrations were statistically equal in the $1^{\text {st }}$ and $2^{\text {nd }}$ regimes, maintaining efficiencies of close to $96 \%$. It is noteworthy that the influent $O \& G$ concentrations were statistically similar to avoid any relationship between these and the removal efficiencies obtained (Table 1).

During the study period, there were five obstructions in the outlet pipe of the Control bioreactor. These obstructions were caused by the buildup of solids (scum) in the three-phase separator. When each obstruction occurred, the top cover of the bioreactor was disconnected to remove the scum. Although the Test bioreactor did not become obstructed because the presence of solid material on its surface was less frequent, the same cleaning procedure was also applied to this reactor. The removed material was analyzed in terms of $O \& G$ and total solids. The $O \& G$ concentration and the percentage of $O \& G$ in the dry residue removed at each cleaning procedure are presented in Table 1 and Figure 1A, respectively. The accumulation of fatty material in the Control bioreactor was at least 4.6 times greater than in the Test bioreactor (Figure 1A). Other authors report sludge flotation as one of the most frequent operational problems in wastewater treatment with high fat content (Miranda et al., 2005; Jeganathan et al., 2006). The amount of O\&G adhered to the biomass was also determined after each operation regime (Figure 1B). There was an increase of fatty material adhered to the anaerobic sludge granules in both bioreactors. However, in the bioreactor fed with pretreated wastewater, accumulation was much lower, with $4.4 \%$ in the $1^{\text {st }}$ regime and $7.8 \%$ in the $2^{\text {nd }}$ regime. In the Control bioreactor, the average percentage of O\&G accumulated in the sludge was $18.2 \%$ and $47.2 \%$ in the $1^{\text {st }}$ and $2^{\text {nd }}$ regimes, respectively.

In the $1^{\text {st }}$ regime, the average biogas production in the Control bioreactor was $436.3 \mathrm{~mL} / \mathrm{d}$ (STP). In the $2^{\text {nd }}$ regime, biogas production increased to $709.5 \mathrm{~mL} / \mathrm{d}$ (STP) until the $95^{\text {th }}$ day of operation, and subsequently was reduced to $143.9 \mathrm{~mL} / \mathrm{d}$ (STP) (Table 1). This sharp decline in biogas production can be associated with accumulation of scum on the surface of the reactor, which made release of the produced biogas difficult, and fat accumulation in the biomass, which reduce the rates of mass transfer (organic matter - anaerobic sludge - biogas). In the Test bioreactor, the biogas
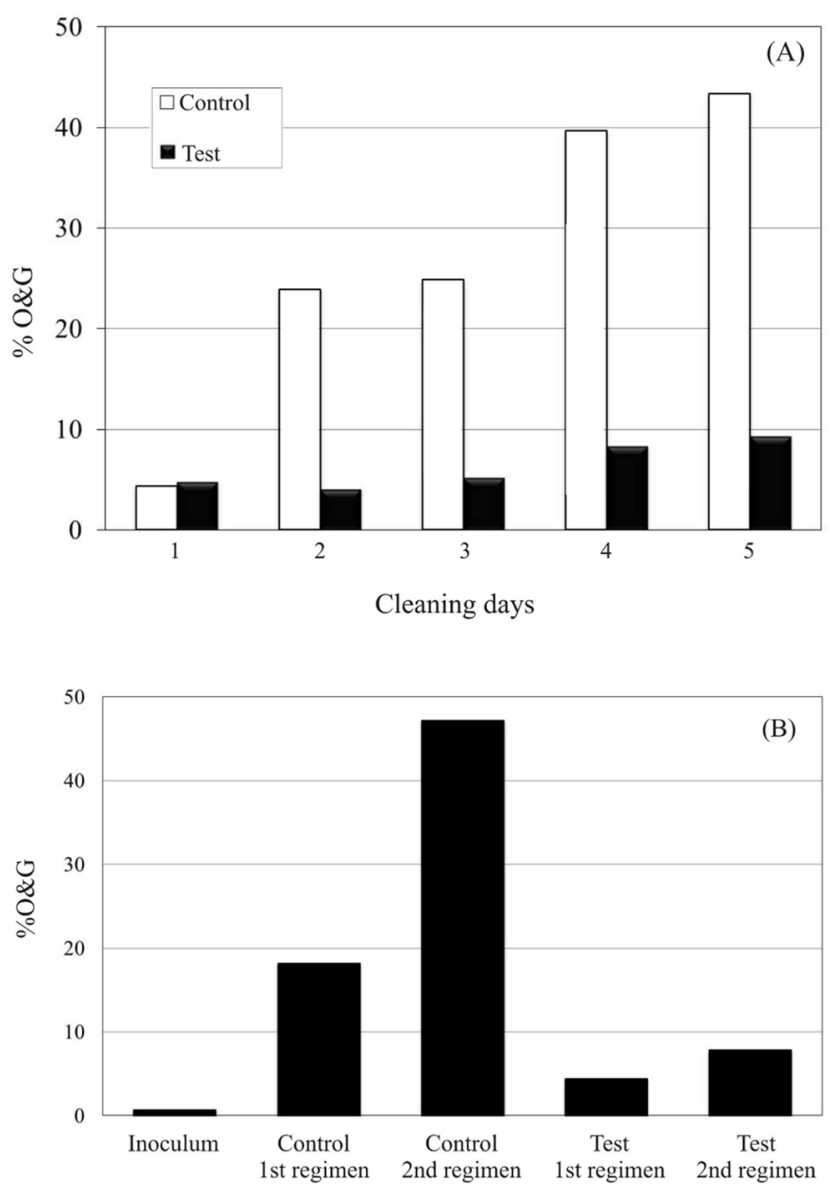

Figure 1. Accumulation of O\&G (\%, dry basis) in the scum (A) and in the anaerobic sludge (B) of Control and Test reactors. At the end of each regime, the three phase separators were cleaned and samples were collected from the scum to establish the $O \& G$ percentage. Sludge samples were also collected at different heights of the bioreactors to determine the percentage of $O \& G$ that adhered to the biomass.

production was almost constant, 598.5 and 662.2 $\mathrm{mL} / \mathrm{d}(\mathrm{STP})$ in the $1^{\text {st }}$ and $2^{\text {nd }}$ regimes, respectively, confirming the stability of biogas production under different organic loads.

The average specific methane production (SMP) was calculated for each regime in the two bioreactors through graphs of cumulative biogas production versus cumulative removed COD. Both bioreactors showed values well below the theoretical limits reported (350 $\mathrm{mL} \mathrm{CH}_{4}(\mathrm{STP}) / \mathrm{g}$ COD removed). The values obtained in the Test bioreactor were higher than those obtained in the Control bioreactor in the $1^{\text {st }}$ and $2^{\text {nd }}$ regimes (Table 1$)$. One hypothesis is that the HRT of UASB reactors (12 to $20 \mathrm{~h}$ ) was not sufficient to permit complete assimilation of the adsorbed COD, which resulted in high removed COD values and low methane production, leading to a lower SMP.

At the end of each regime, the biomass within the bioreactors was evaluated and quantified as volatile suspended solids (VSS) (Table 1). The initial 
concentration of sludge in the reactor was $14.7 \mathrm{~g}$ $\mathrm{VSS} / \mathrm{L}$. In the $1^{\text {st }}$ regime, the biomass concentration increased by $37.4 \%$ and $61.2 \%$ in the Control and Test bioreactors, respectively. In the $2^{\text {nd }}$ regime, the biomass concentration decreased in both bioreactors. This decrease was significant in the Control bioreactor due to substantial formation of scum and sludge flotation with subsequent loss of biomass in the bioreactor output. In the Test bioreactor, the loss of biomass from the $1^{\text {st }}$ to the $2^{\text {nd }}$ regime was low, remaining within the range of optimal concentration recommended for UASB reactors (20 - $40 \mathrm{~g} \mathrm{VSS/L)} \mathrm{(Stronach} \mathrm{et} \mathrm{al.,}$ 1986). Some authors have reported that wastewaters with high fat and protein contents are not appropriate for granulation of the biomass in UASB reactors. Fat can impair the reactor performance, envolving the granule, which decreases the mass transfer and causes washing of cells or inhibition of the activity (Alves et al., 2009). The anaerobic sludge structure could be important for mineralization of long-chain fatty acids (LCFA), and suspended sludge could be more advantageous over granular sludge due to its higher capacity of LCFA adsorption and degradation (Pereira et al. 2002; 2004). However, other authors state that suspended and flocculent sludges, which have a higher specific surface area, could suffer much more inhibition than granular sludges (Hwu, 1997). That author recommended the use of granular sludges as appropriate inocula for reactors treating lipid (fats, oils, and greases) wastewaters, to decrease the toxic impact of their hydrolysis products-LCFA. Disintegration of the granules of sludge was not observed in either bioreactors of the present study, but some authors state that at neutral $\mathrm{pH}$ LCFA act as surfactants, lowering the surface tension of the medium and causing sloughingoff from granular sludge and the selective washout of the acetogenic microorganisms (Alves et al., 2009).

In the bioreactor fed with the pretreated wastewater, the addition of biosurfactant and enzymes improved fat assimilation by microorganisms, allowing the VSS concentration to remain high. The statistical analysis conducted with average values obtained from evaluating both UASB reactors (Table 1) found significant differences that were always favorable to the operation of the Test bioreactor for COD removal, $O \& G$ removal, $O \& G$ in the scum, and percentage of methane in the $1^{\text {st }}$ and $2^{\text {nd }}$ regimes. These results demonstrate the benefit of the biosurfactant and enzyme consortia pretreatment as a preliminary step for the treatment of wastewaters containing high fat content in UASB reactors.

\section{Techno-economic evaluation}

A cost analysis was carried out for two process scenarios. The first process scenario was related to the conventional treatment of wastewaters from poultry slaughterhouses, similar to that adopted by the industry that provided the wastewater used in this study (Figure 2A). The usual wastewater treatment was divided into four operations: equalization, chemically assisted (ferric chloride and anionic flocculant) dissolved air flotation (DAF), tri-decanter (to separate the float, which is bagged in 20 liter plastic bags and destined for the landfill), and anaerobic reactor (which receives the effluent streams of the FAD and tri-decanter).

In the second process scenario, the plant was set up to implement the alternative technology proposed in this study (addition of biosurfactant and enzyme consortia) employing the optimum conditions found (Figure 2B). The duration of each batch cycle was 4 h. This was achieved by assuming the simultaneous operation of three identical equalization tanks. In each batch cycle, one tank is always loaded with wastewater, enzyme consortia and biosurfactant, one tank is always treating wastewater, and the third tank is always uploading the treated wastewater. Three equalization tanks are required in order to ensure a continuous flow of treated wastewater at the same flow rate $\left(31.25 \mathrm{~m}^{3} / \mathrm{h}\right)$. The total number of batch cycles will be 1872 batches per year.

Table 2 presents the cost of the installed equipment, the fixed capital investments, the working capital, and total capital investment for implementation of the conventional and the proposed wastewater pretreatment plants. The fixed capital investment for the proposed process was about $60 \%$ lower than the conventional plant, representing a cheaper capital investment. The higher total installed equipment cost of the conventional plant is due to the equipments (dissolved air flotation; tri-decanter centrifuge; and mixing tank) used to remove insoluble material in this type of wastewater treatment, especially in the form of fats (Table 2). The fatty materials can cause operational problems in biological treatment systems when they are not removed or properly pretreated. However, with appropriate technology for solubilization and hydrolysis, microbial communities can effectively convert lipids into methane, which can be used as an alternative energy source (Alves et al., 2009). The energy efficiency of the anaerobic processes depends on the organic matter in the wastewater and can be especially high when dealing with lipids and long-chain fatty acids (LCFA), which are often found in industrial 


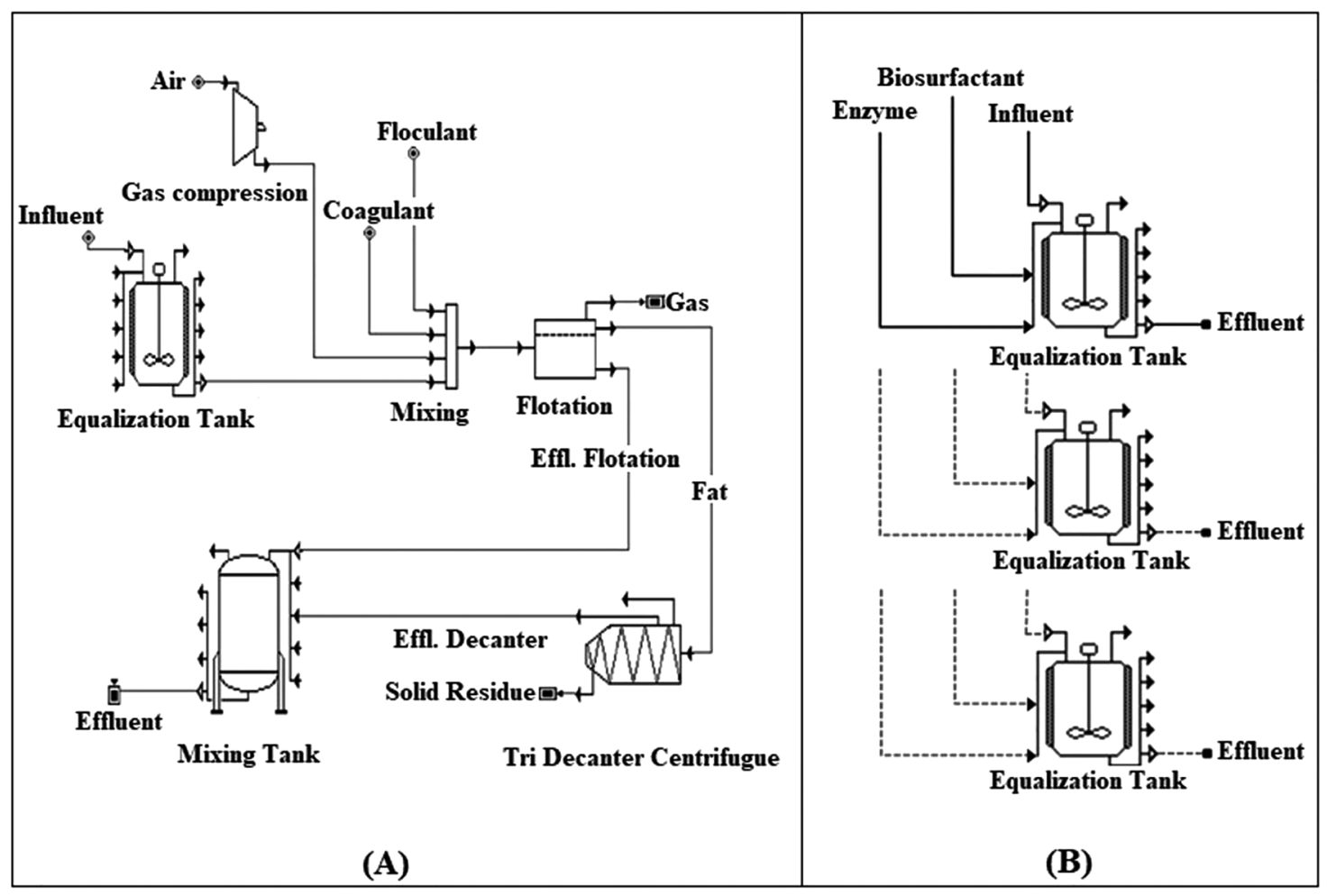

Figure 2. Flow chart for the treatment of wastewaters from poultry processing using the conventional technology (A), and the alternative technology proposed in this study (B). In the conventional technology, the treatment is divided into four operations: equalization, chemically assisted dissolved air flotation (DAF), tri-decanter, and anaerobic reactor (mixing tank). In the alternative technology, three equalization tanks are required in order to ensure a continuous flow of treated wastewater.

effluents as the major hydrolysis product (Sousa et al., 2007). Their removal by physical-chemical processes before the anaerobic treatment is a common practice. However, LCFA have high energy potential and could be used to generate profits.

Table 3 shows the operating costs for the conventional and the proposed processing scenarios. The costs related to labor requirements, fixed capital related expenses, disposal of solid waste, and utilities are higher for the conventional technology. However, the alternative plant requires a greater expense with raw material than the conventional plant. Overall, the operating cost of the novel treatment plant is $6 \%$ lower than the operating cost of the conventional plant. The waste disposal cost (Table 3) refers to the cost of disposal in landfill. This solid residue is composed practically of fats, separated from the effluent by physicochemical process, which could be converted into methane, a source of bioenergy. Its use would lower operating cost by substituting some of the electricity supplied by the grid with cogeneration from the methane produced. Depending on the method used in industrial plants, O\&G removals from $50 \%$ to $99 \%$ (Nardi et al., 2008; Del Nery et al., 2007; Del Nery et al., 2013) can be obtained. Considering the flow and
O\&G concentration in the effluent of the industry in question $\left(31.25 \mathrm{~m}^{3} / \mathrm{h}\right.$ and $\left.1200 \mathrm{mg} / \mathrm{L}\right)$ and an average removal of $75 \%$, about $675 \mathrm{~kg} / \mathrm{d}$ of fatty material could be removed from DAF. Based on the theoretical potential of methane production of the lipids $-0.99 \mathrm{~L}$ $\mathrm{CH}_{4} / \mathrm{g}$ (Alves et al., 2009), up to $668 \mathrm{~m}^{3} \mathrm{CH}_{4} / \mathrm{d}$ could be generated from this residue.

In the proposed process, the cost of solid waste disposal is zero, since the fatty material is solubilized by the addition of biosurfactant and can thus be hydrolyzed by the action of enzymes. This, however, contributes to a higher expenditure for raw materials that is approximately $41.4 \%$ of the operating cost of the flow sheet for the proposed process. The use of this alternative technology also enables an increase in biogas production and longer maintenance of the secondary treatment unit that receives the pretreated effluent, because all the fatty materials are prehydrolyzed, which will facilitate action of anaerobic microorganisms, thereby reducing the accumulation of such material and operational problems.

For a plant treating $234,000 \mathrm{~m}^{3}$ of wastewater per year, the cost of treatment per $\mathrm{m}^{3}$ of treated effluent will be $3.07 \mathrm{US} \$ / \mathrm{m}^{3}$ for the conventional process and $2.88 \mathrm{US} \$ / \mathrm{m}^{3}$ for the novel process. This means that 
Table 2. Estimation of fixed capital investment for the conventional and the proposed processes for pretreatment of poultry slaughterhouse wastewater.

\begin{tabular}{|c|c|c|c|c|c|c|}
\hline Equipment & Quantity & $\begin{array}{l}\text { Volume/ } \\
\text { capacity }\end{array}$ & Material & Fob Cost (US\$) $)^{\mathrm{a}}$ & Bare Module Factor & $\begin{array}{l}\text { Installed Equipment } \\
\text { Cost (US\$) }\end{array}$ \\
\hline \multicolumn{7}{|c|}{ Conventional Technology } \\
\hline Equalization tank & 1 & $30 \mathrm{~m}^{3}$ & Concrete & $4,709.00$ & 4.07 & $19,165.63$ \\
\hline Dissolved air flotation & 1 & $30-35 \mathrm{~m}^{3} / \mathrm{h}$ & Fiberglass & $55,310.00$ & 4.07 & $225,111.70$ \\
\hline $\begin{array}{l}\text { Tri-Decanter } \\
\text { centrifuge }\end{array}$ & 1 & $10-15 \mathrm{~m}^{3} / \mathrm{h}$ & Stainless steel & $64,962.00$ & 2.60 & $168,901.20$ \\
\hline Mixing tank & 1 & $30 \mathrm{~m}^{3}$ & Fiberglass & $2,784.00$ & 4.07 & $11,330.88$ \\
\hline \multicolumn{6}{|l|}{ Subtotal } & $424,509.41$ \\
\hline \multicolumn{6}{|c|}{ Fixed Capital Investment (installed equipment * 1.2) } & $509,411.29$ \\
\hline \multicolumn{6}{|l|}{ Working Capital } & $12,051.50$ \\
\hline \multicolumn{6}{|c|}{ Total Capital Investment } & $521,462.79$ \\
\hline \multicolumn{7}{|l|}{ Alternative Technology } \\
\hline Equalization tank & 3 & $158 \mathrm{~m}^{3}$ & Concrete & $13,686.00$ & 4.07 & $55,702.02$ \\
\hline \multicolumn{6}{|l|}{ Subtotal } & $167,106.06$ \\
\hline \multicolumn{6}{|c|}{ Fixed Capital Investment (installed equipment * 1.2) } & $200,527.27$ \\
\hline \multicolumn{6}{|l|}{ Working Capital } & $151,867.50$ \\
\hline \multicolumn{6}{|c|}{ Total Capital Investment } & $352,394.77$ \\
\hline
\end{tabular}

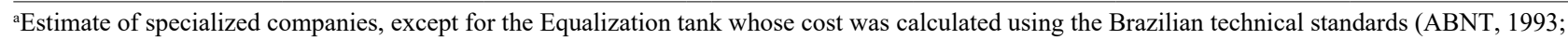
2004) and procedures described in Peter et al. (2003).

Table 3. Annual operating cost (US\$) required for wastewater pretreatment employing the conventional and the proposed process flowsheets.

\begin{tabular}{lcc}
\hline \multirow{2}{*}{ Item } & \multicolumn{2}{c}{ Operating Cost (US\$) } \\
\cline { 2 - 3 } & Conventional Technology & Alternative Technology \\
\hline Raw material $\left(\mathrm{C}_{\mathrm{RM}}\right)$ & 42,756 & 604,204 \\
Labor $\left(\mathrm{C}_{\mathrm{OL}}\right)$ & 16,350 & 9,810 \\
Treatment / disposal of waste $\left(\mathrm{C}_{\mathrm{WT}}\right)$ & 297,229 & 0 \\
Utilities $\left(\mathrm{C}_{\mathrm{UT}}\right)$ & 217,851 & 427 \\
\hline Annual operating cost $\left(\mathrm{C}_{\mathrm{OM}}\right)^{\mathrm{a}}$ & 717,838 & 675,088 \\
\hline
\end{tabular}

acalculated using Equation 2.

the process proposed in this study could replace the conventional process as it requires both less capital investment and operating cost per $\mathrm{m}^{3}$ of treated effluent (6.0\% less operating cost).

\section{CONCLUSIONS}

This study showed a technically and economically viable alternative process to pretreat poultry slaughterhouse wastewater. The monitoring of UASB reactors proved the technical feasibility of pretreatment using enzymes and rhamnolipid for $4 \mathrm{~h}$ at $30^{\circ} \mathrm{C}$, to obtain higher removal rates of COD and $\mathrm{O} \& \mathrm{G}$ as well as higher methane production without frequent operational problems. The economic analysis of the novel plant (without considering methane production) revealed that this alternative technology to pretreat wastewater with high content of fat has lower installation and operational costs than the traditional technology (using floaters/chemicals) with rates of $60 \%$ and $6 \%$, respectively.

\section{ACKNOWLEDGEMENTS}

This work was supported by funds from the Conselho Nacional de Pesquisa e Desenvolvimento (CNPq).

\section{NOMENCLATURE}

Acronyms

$\mathrm{CH}_{4}$ - methane

CMC - critical micelle concentration $(\mathrm{mg} / \mathrm{L})$

COD - chemical oxygen demand $(\mathrm{mg} / \mathrm{L})$

DAF - dissolved air flotation

HRT - hydraulic retention time (h)

LCFA - long-chain fatty acids

$\mathrm{O} \& \mathrm{G}$ - oil and grease 
OLR - organic loading rate $\left(\mathrm{kg} \mathrm{COD} / \mathrm{m}^{3} . \mathrm{d}\right)$

SMA - specific methanogenic activity $\left(\mathrm{g} \mathrm{COD}_{\mathrm{CH} 4} /\right.$ gVSS.d)

SMP - specific methane production $\left(\mathrm{mL} \mathrm{CH}_{4}(\mathrm{STP}) /\right.$ g COD removed)

SEP - solid enzymatic preparation

STP - standard temperature and pressure

UASB - upflow anaerobic sludge blanket

VFA - volatile fatty acids concentration (mg Acetid $\mathrm{acid} / \mathrm{L})$

VSS - volatile suspended solids $(\mathrm{mg} / \mathrm{L})$

Symbols

$\mathrm{C}_{\mathrm{BM}}$ - installed equipment cost

$\mathrm{C}_{\mathrm{OL}}-\operatorname{cost}$ of labor (operating labor and direct supervision)

$\mathrm{C}_{\mathrm{p}}$ - cost to purchase equipment

$\mathrm{C}_{\mathrm{RM}}$ - cost of raw materials

$\mathrm{C}_{\mathrm{UT}}$ - cost of utilities

$\mathrm{C}_{\mathrm{WT}}$ - cost of waste treatment

$\mathrm{F}_{\mathrm{BM}}$ - Bare module factor

$\mathrm{F}_{\mathrm{CI}}$ - cost of supplies, laboratory charges and fixed capital related costs (equipment maintenance and depreciation)

\section{REFERENCES}

ABNT. Associação Brasileira de Normas Técnicas (Brazilian Association of Technical Standards) . NBR 7229 - Projeto, Construção e Operação de Sistemas de Tanques Sépticos - Procedimento (Project, Construction and Operation of Septic Tank Systems - Procedure), ABNT, Rio de Janeiro, p. 15 (1993).

ABNT. Associação Brasileira de Normas Técnicas

(Brazilian Association of Technical Standards). NBR 6118 - Projeto de Estruturas de Concreto Procedimento (Design of Structural Concrete Procedure), ABNT, Rio de Janeiro, p. 22 (2004).

Al-Mutairi, N.Z., Al-Sharifi, F.A. and Al-Shammari, S.B., Evaluation Study of a Slaughterhouse Wastewater Treatment Plant Including ContactAssisted Activated Sludge and DAF, Desalination, 225, No. 1-3, 167-175 (2008).

Alves, M.M., Pereira, M.A., Sousa, D.Z., Cavaleiro, A.J., Picavet, M., Smidt, H. and Stams, A.J.M., Waste Lipids to Energy: How to Optimize Methane Production from Long-chain fatty acids (LCFA), Microbial Biotechnology, 2, No. 5, 538-550 (2009). Angelidaki, I. and Sanders, W., Assessment of the Anaerobic Biodegradability of Macropollutants, $\mathrm{Re} /$ Views in Environmental Science \& Bio/ Technology, 3, No. 2, 117-129 (2004).
Cooper, D.G. and Goldenberg, B.G., Surface-active Agents from Two Bacillus Species. Applied and Environmental Microbiology, 53, No. 2, 224-229 (1987).

Cooper, D.G., Zajic, J.E. and Gerson, F., Production of Surface-active Lipids by Corynebacterium lepus, Applied and Environmental Microbiology, 37, No. 1, 4-10 (1979).

Damasceno, F.R.C., Cammarota, M.C. and Freire, D.M.G., The Combined Use of a Biosurfactant and Enzyme Preparation to Treat Effluent With a High Fat Content, Colloids and Surfaces B: Biointerfaces, 95, 241-246 (2012).

Daverey, A. and Pakshirajan, K., Pretreatment of Synthetic Dairy Wastewater Using the Sophorolipid-Producing Yeast Candida bombicola, Applied Biochemistry and Biotechnology, 163, No. 6, 720 (2011).

Del Nery, V., Nardi, I.R., Damianovic, M.H.R.Z., Pozzi, E., Amorim, A.K.B. and Zaiat, M., Long-term Operating Performance of a Poultry Slaughterhouse Wastewater Treatment Plant. Resources, Conservation and Recycling, 50, No. 1, 102-114 (2007).

Del Nery, V., Damianovic, M.H.R.Z., Pozzi, E., Nardi, I.R., Caldas, V.E.A., Pires, E.C., Long-term Performance and Operational Strategies of a Poultry Slaughterhouse Waste Stabilization Pond System in a Tropical Climate, Resources, Conservation and Recycling, 71, No. 1, 7-14 (2013).

Dors, G., Mendes, A.A., Pereira, E.B., Castro, H.F. and Furigo Jr., A., Simultaneous Enzymatic Hydrolysis and Anaerobic Biodegradation of Lipid-rich Wastewater from Poultry Industry, Applied Water Science, 3, No. 1, 343-349 (2013).

Du Noüy, P.L., An Interfacial Tensiometer for Universal Use, Journal of General Physiology, 7, No. 5, 625 (1925).

Freire, D.M.G., Teles, E.M.F., Bon, E.P.S. and Sant'Anna Jr., G.L.,Lipase Production by Penicillum restrictum in Laboratory-scale Fermenter: Media Composition, Agitation and Aeration. Applied Biochemistry and Biotechnology, 63, No. 1, 409421 (1997).

Gombert, A.K., Pinto-Lopes, A., Castilho, L.R. and Freire, D.M.G., Lipase Production by Penicillium restrictum in a Solid-state Fermentation Using Babassu Oil Cake as Substrate, Process Biochemistry, 35, No. 1-2, 85-90 (1999).

Greenberg, A.E., Clesceri, L.S. and Eaton, A.D., Standard Methods for the Examination of 
Water and Wastewater. American Public Health Association/American Water Works Association/ Water Pollution Control Federation, New York (2005).

Gutarra, M.L., Cavalcanti, E.D., Castilho, L.R., Freire, D.M.G., and Sant'anna Jr., G.L., Lipase Production Solid State Fermentation: Cultivation Conditions and Operation of a Packed-bed Bioreactor, Applied Biochemistry and Biotechnology, 121, No. 1-3, 105-116 (2005).

Hwu, C.-S., Enhancing Anaerobic Treatment of Wastewater Containing Oleic Acid, Ph.D. thesis, Wageningen Agricultural University, Wageningen, The Netherlands (1997).

Jeganathan, J., Nakhla, G. and Bassi, A., Long-term Performance of High-rate Anaerobic Reactors for the Treatment of Oily Wastewater, Environmental Science and Technology, 40, No. 20, 6466-6472 (2006).

Jeganathan, J., Nakhla, G. and Bassi, A., Oily Wastewater Treatment Using a Novel Hybrid PBRUASB System, Chemosphere, 67, No. 8, 14921501 (2007).

Masse, L., Kennedy, K.J. and Chou, S., The Effect of an Enzymatic Pretreatment on the Hydrolysis and Size Reduction of Fat Particles in Slaughterhouse Wastewater, Journal of Chemical Technology and Biotechnology, 76, No. 6, 629-635 (2001).

Masse, L., Massé, D.I. and Kennedy, K.J., Effect of Hydrolysis Pretreatment on Fat Degradation During Anaerobic Digestion of Slaughterhouse Wastewater. Process Biochemistry, 38, No. 9, 1365-1372 (2003).

Miranda, L.A.S., Henriques, J.A.P. and Monteggia, L.O., A full-scale UASB Reactor for Treatment of Pig and Cattle Slaughterhouse Wastewater With a High Oil and Grease Content, Brazilian Journal of Chemical Engineering, 22, No. 4, 601-610 (2005).

Nakhla, G., Al-Sabawi, M., Bassi, A. and Liu, V., Anaerobic Treatability of High Oil and Grease Rendering Wastewater, Journal of Hazardous Materials, B102, 243-255 (2003).

Nardi, I.R., Fuzi, T.P. and Del Nery, V., Performance Evaluation and Operating Strategies ofDissolved-air Flotation System Treating Poultry Slaughterhouse Wastewater. Resources, Conservation and Recycling, 52, No. 3, 533 (2008).

Pereira, M.A., Pires, O.C., Mota, M. and Alves, M.M., Anaerobic Degradation of Oleic Acid by Suspended and Granular Sludge: Identification of
Palmitic Acid as a Key Intermediate, Water Science and Technology, 45, No 10, 139-144 (2002).

Pereira, M.A., Sousa, D.Z., Mota, M. and Alves, M.M., Mineralization of LCFA Associated with Anaerobic Sludge: Kinetics, Enhancement of Methanogenic Activity, and Effect of VFA, Biotechnology and Bioengineering, 88, No. 4, 502-511 (2004).

Peters, M.S., Timmerhaus, K.D. and West, R.E., Plant Design and Economics for Chemical Engineers. McGraw-Hill, Boston (2003).

Pham, T.H., Webb, J.S. and Rehm, B.H.M., The Role of Polyhydroxyalkanoate Biosynthesis by Pseudomonas aeruginosa in Rhamnolipid and Alginate Production as Well as Stress Tolerance and Biofilm Formation, Microbiology, 150, No. 10, 3405-3413 (2004).

Santa Anna, L.M., Sebastian, G.V., Menezes, E.P., Alves, T.L.M., Santos, S., Pereira Jr., N. and Freire, D.M.G., Production of Biosurfactants from Pseudomonas aeruginosa PA1 Isolated in Oil Environments, Brazilian Journal of Chemical Engineering, 19, No. 2, 159-166 (2002).

Santos, A.S., Sampaio, A.W., Vasquez, G.S., Santa Ann,a L.M., Pereira Jr., N. and Freire, D.M.G., Evaluation of Different Carbon and Nitrogen Sources in Production of Rhamnolipids by a Strain of Pseudomonas aeruginosa, Applied Biochemistry and Biotechnology, 98, No. 1, 1025-1035 (2002).

Sousa, D.Z., Pereira, M.A., Stams, A.J.M., Alves, M.M. and Smidt, H., Microbial Communities Involved in Anaerobic Degradation of Unsaturated or Saturated Long-chain Fatty Acids, Applied and Environmental Microbiology, 73, No. 4, 1054-1064 (2007).

Stronach, S.M., Rudd, T. and Lester, J.N., Anaerobic Digestion Processes in Industrial Wastewater Treatment. Springer-Verlag, Berlin (1986).

Turton, R., Bailie, R.C., Whiting, W.B., Shaeiwitz, J.A., and Bhattacharyya, D., Analysis, Synthesis, and Design of Chemical Processes. International Series in the Physical and Chemical Engineering Sciences. Prentice Hall, United States (2012).

Ulrich,G.D. and Vasudevan,P.T., ChemicalEngineering, Process Design and Economics, a Practical Guide. Process Publishing, New Hampshire (2004).

Valladão, A.B.G., Sartore, P.E., Freire, D.M.G. and Cammarota, M.C., Evaluation of Different Pre-hydrolysis Times and Concentration of the Enzymatic Pool in the Biodegradability of Poultry Slaughterhouse Wastewater with High Fat Content, Water Science and Technology, 60, No. 1, 243-249 (2009). 